\section{CHRISTIAN BORCH}

\section{MASSE-}

\section{REPRASENTATION}

STEFAN JONSSON

\section{Crowds and Democracy: The Idea and Image of the Masses from Revolution to Fascism}

New York \& London: Columbia University

Press, 2013, 321 sider

Crowds and Democracy er andet - og glimrende bind i Stefan Jonssons stort anlagte massetrilogi. Første bind udkom i 2008 under titlen A Brief History of the Masses: Three Revolutions og analyserede europæiske forestillinger om massen fra tiden omkring Den Franske Revolution til I989. Crowds and Democracy er et længere og på flere måder mere detaljeret studie, hvor sidstnævnte kvalitet må tilskrives, at bogen fokuserer på en både geografisk og tidsligt mere afgrænset tematik. Således demarkerer Jonsson selv bogens begyndelses- og endepunkter med I895, hvor Gustave Le Bon udgav sin berømt/berygtede afhandling om Massernes psykologi, og 1939, hvor Hermann Broch formulerede sit ikke-realiserede forslag om oprettelsen af et Research Institute for the Study of Political Psychology and Mass Insanity på Princeton University. På trods af denne tidslige spændvidde, samler Jonssons væsentlige interesse sig om forestillinger om massen, som de tog sig ud i Weimartiden (bogen beskæftiger sig med tyske såvel som østrigske forestillinger om massen), og Le Bon og andre massepsykologer fra slutningen af det I9. århundrede figurerer primært som et bagtæppe på baggrund af hvilket, egenarten af Weimartidens massediskussioner analyseres.

De tidslige og geografske forskelle til trods er der også store fællestræk mellem A Brief History of the Masses og Crowds and Democracy. Dette gælder navnlig Jonssons metode, som består i at privilegere æstetiske udtryksformer over fx akademiske tekster. Med Jonssons egne ord: "I am convinced that the aesthetic images of the mass in Weimar culture tell us far more about the political conflicts and historical predicament of this society than we are likely to pick up if we limit our interest to the masses found in the scholarly and political context” (I2-I3, kursiv i originalen). Af samme grund hævder Jonsson, at han er særligt interesseret $\mathrm{i}$ masserne, sådan som de repræsenteres inden for kunst, fotografi, film, litteratur, teater, dans og arkitektur (I2). Selv om det er sandsynligt, at der finder en vekselvirkning sted mellem æstetiske og fx akademiske repræsentationer af masserne (og af andre fænomener), er det ikke indlysende for mig, hvorfor det æstetiske a priori må tilskrives denne forrang, og i realiteten er Jonsson heller ikke ubetinget tro mod sin programerklæring. Langt den overvejende del af bogen er således viet studiet af massetænkning, som man finder den i Weimartidens sociologiske, socialteoretiske og politiske tænkning - fremfor af massen som den forekommer i æstetetiske repræsentationer. Et eksempel på dette er analysen af Sigmund Freuds massepsykologi (kap. 3 i Crowds and Democracy), hvor det først er efter 20 sider, at Freuds tekstlige korpus for alvor forlades til fordel for en diskussion af relationen mellem Freuds tænkning og æstetiske repræsentationer af massen.

Bogens centrale analytiske pointe og bidrag angår relationen mellem masse, repræsentation og demokrati. Gennem hele bogen argumenterer Jonsson for, at den enorme optagethed af masserne, man uden tvivl kan identificere i Weimartiden - på tværs af kunst, samfundsteori og politisk aktivisme (af alskens art og overbevisning) - i bund og grund handler om periodens dybt ustabile politiske situation og, nok så vigtigt, om at finde nye måder at tænke og begribe politisk repræsentation på. Eller mere præcist: Massernes allestedsnærvær, deres forekomst ikke alene på gaderne eller via nye medieteknologier, men også og ikke mindst som genstand for intellektuel observation og analyse, skyldes, som Jonsson 
formulerer det, en afgrundsdyb kløft mellem det karakter: voldelig masse, som fortjener at blive eksisterende parlamentariske system på den ene bekæmpet, eller en gruppe af individer, som kæmside og efterspørgslen på nye og mere adækvate per en retfærdig kamp, men som undertrykkes af måder at repræsentere folkets sociale passioner regimet.

på på den anden. Denne pointe udfoldes gennem en detaljerig diskussion af en lang række tekster og æstetiske masserepræsentationer suppleret med en bred vifte af historiske fakta.

Crowds and Democracy er inddelt i fire store kapitler, omrammet af en indledning og afslutning. Kapitlerne følger ikke en streng kronologi, men er i stedet organiseret efter et optisk princip, hvor masserne først behandles på fysisk afstand og derefter stadig tættere på. Mere konkret: Hvor første kapitel analyserer massesemantik, som betragter massen distanceret, på afstand, diskuterer fjerde kapitel massesemantik, som hævder, at masserne må oplæres i, hvordan de med kameraet som våben skal repræsentere arbejdernes vilkå helt tæt på (i hjemmet, på fabrikken mv.). Dette er et originalt organiseringsprincip, men det skaber også visse kategoriseringsudfordringer. Hvo Jonsson $\mathrm{fx}$ vælger at fokusere sin diskussion af Elias Canettis massetænkning i de første kapitler med begrundelsen at Canetti beskrev massen som et (distanceret) bjerg, der skulle bestiges, kunne man lige så vel argumentere for, at Canetti rettelig burde behandles i fjerde kapitel, eftersom hans erklærede ambition var at beskrive massen indefra (og altså uden distance til objektet).

Alle fire kapitler rummer bunker af interessante analyser og iagttagelser. Første kapitel er, ligesom et centralt kapitel $i$ Canettis erindringer (såvel som i Sven Hanuscheks store Canetti-biografi fra 2005: Elias Canetti. Biographie), viet masseoptøjerne i Wien den I5. juli 1927, hvor Justitspaladset blev sat i flammer under frustration over en retlig dom, og hvor politiet gik brutalt til værks i bekæmpelsen af massen. Kapitlets højdepunkt er en diskussion af forskellige visuelle repræsentationer af samme masse. Her viser Jonsson overbevisende, hvordan det æstetiske - her fotografiet - indgår i en vigtig kamp om repræsentationen af massens
Andet kapitel diskuterer massebegreber i sociologien og litteraturen. Vægten er her på det formalsociologiske program, som sociologer som Georg Simmel, Gerhard Colm og Theodor Geiger bekendte sig til, og som i Jonssons læsning diskvalificerede massen som sociologisk restbegreb. Kapitlets højdepunkt er dog diskussionen af litterære repræsentationer af massen, navnlig Brochs litterære skildring af massen som central social transformationsfigur - med vægten lagt på Sovngangerne. Tredje kapitel fokuserer i høj grad på Freuds massepsykologi og går derpå over i en interessant diskussion af opkomsten af en postindividualistisk massetænkning. Idéen i denne massetænkning, som Jonsson relaterer til Freud, Canetti og Robert Musil, er at opgive modsætningen mellem masse og individ, som var central for megen massepsykologi i slutningen af det 19 . århundrede, for i stedet at betragte forholdet mellem masse og individ som flydende og polerne som gensidigt konstituerende.

Kapitel 4 er på mange måder bogens mest æstetisk rettede og spænder interessant fra foto(plastisk)montage til totalteater. Kapitlets højdepunkt er i mine øjne Jonssons diskussion af bestræbelserne på, inden for rammerne af magasinet Der Arbeiter-Fotograf, at oplære de arbejdende masser $i$ at dokumentere deres dagligliv fotografisk. Hensigten bag projektet var, som Jonsson skriver, at opnå en form for adækvat selv-repræsentation af massen, som ikke reducerede denne til en samfundsdestruktiv kraft, men som - nedefra - beskrev og dokumenterede arbejdernes vilkår, herunder vilkår som ellers typisk blev udgrænset fra politiske diskussioner. Under overskriften "Learning to hold a camera" beskriver et afsnit kapitlet detaljeret, hvordan Der Arbeiter-Fotograf iscenesatte et omfattende program for fotografiskgenereret transformation af arbejderne fra masse til klasse. Interessant nok fortolker Jonsson primært dette program affirmativt som et bud på, hvordan en repræsentation af massen faktisk kunne tage sig ud. Dermed overser hans analyse dog den paradoksalitet, der ligger i, at Der Arbeiter Fotografi virkeligheden endte med at bekræfte den fordom, som bl.a. Le Bon gjorde sig til talsmand for, nemlig at massen er ufornuftig og derfo bør ledes. I det hele taget er denne paradoksale oplysningsarv underbelyst $\mathrm{i}$ Jonssons bog (se for en interessant diskussion af dette aspekt i stedet Sloterdijks Masse og foragt. Essay om kulturkampe $i$ det moderne samfund).

En overordnet vurdering af Jonssons bog mà ikke alene hvile på dens interne sammenhæng (som generelt er formidabel) og dens sproglige fremstilling (som er suveræn), men også på, hvilke indsigter den bibringer den eksisterende litteratur på feltet. Her vil jeg tillade mig at sammenligne Crowds and Democracy med min egen The Politics of Crowds: An Alternative History of Sociology, som udkom I,5 år før Jonssons på Cambridge University Press (men som ikke citeres i Crowds and Democracy). Næppe overraskende berører de to bøger en lang række af de samme personer (i tillæg til de allerede nævnte (Canetti, Broch, Geiger, Colm, Freud, Simmel), fx Hannah Arendt, Alfred Vierkandt, Werner Sombart, Wilhelm Vleugels, Max Weber, Theodor Adorno, Wilhelm Reich, Siegfried Kracauer, Walter Benjamin og Ernst Jünger), men de gør det med forskellig vægt. Hvor The Politics of Crowds omhandler sociologisk massetænkning fra slutningen af det I9. århundrede til i dag, med særlig vægt på Frankrig, Tyskland og USA, og derfor kun tildeler Weimarperioden et enkelt kapitel, går Jonsson mere (i nogle tilfælde dog mindre) $i$ dybden med en lang række af ovennævnte skikkelser, ligesom navnlig hans analyse af æstetiske repræsentationer af massen har mere at byde på Her leverer Jonssons bog altså klart et bidrag.

Sammenligningen af de to bøger viser dog også påfaldende udeladelser i Crowds and Democracy. Fx er det overraskende, at politisk venstre- fløjstænkning ikke vies en systematisk analyse. Der er, som eksemplet med Der Arbeiter-Fotograf viser, forskellige bud i bogen på, hvordan periodens massetænkning forlenes med venstrefløjsbestræbelser, men der savnes en mere omfattende, eksplicit analyse af dette. Uden at jeg vil hævde selv at have leveret en sådan i min bog (så lang fra endda), viser The Politics of Crowds dog, hvorledes massetænkningen stod centralt hos tænkere som Rosa Luxemburg, Karl Kautsky og Rober Michels (som senere slog over i et fascistisk spor). Jonsson nævner Luxemburg i forbifarten tre steder i bogen, men hendes diskussioner af forholdet mellem parti og masse behandles ikke, selv om hendes påpegning af massens mulighed for at lære i selve sin aktion giver et interessant alternativ til den oplysningsfigur, som ligger til grund for $\mathrm{Der}$ Arbeiter-Fotograf.

På samme måde kunne en mere systematisk diskussion af den franske massepsykologi i slutningen af det I9. århundrede have afværget en tendens til at dømme Weimartidens massetænkning mere original, end den måske er. Her tænker jeg navnlig på Jonssons interessante diskussion af en postindividuel massefigur. Havde Jonsson ikke centreret sin diskussion af den tidlige massepsykologi omkring Le Bon (som utvivlsomt var den mest læste, men også på mange måde den mest vulgære massepsykolog fra slutningen af det 19 århundrede), men ligeså meget omkring Gabriel Tarde, ville han således kunne have udledt samme konklusion: Modsat hvad Jonsson hævder (I28) afviste Tarde ikke suggestionstænkning. Suggestion og somnambulisme var tværtimod centrale begreber $i$ hans bestemmelse af samfundet som, ja, en postindividuel masse. I lyset af Jonssons fremgangsmåde, hvor massetænkningen skal analyseres i spændingsfeltet mellem æstetik, politik og socialteori, savner man endelig en diskussion af Hitlers Mein Kampf (à la Knausgårds Min kamp).

Når det er sagt, er styrkerne ved Jonssons bog imidlertid klart betydeligere end sådanne udeladelser. Crowds and Democracy er i sandhed et cen- 
tralt bidrag til litteraturen om massernes rolle i det moderne samfund, herunder deres centrale status i spændingsfeltet mellem demokrati og repræsentation. Bogen sætter en høj standard for trilogiens afsluttende værk, som må afventes med spænding.

Christian Borch er lektor ved Institut for Ledelse, Politik og Filosofi, Copenhagen Business School 